\title{
Financial Management Capacity, Accountability, Own Income Generation, Revenue Diversification and Financial Sustainability in Charities of Malaysia
}

\author{
SHARON CHEUK*1, LIAN KEE PHUA ${ }^{2}$, A.K SITI-NABIHA ${ }^{3}$, SALAWATI SAHARI ${ }^{1}$, ESMIE O. NICHOL ${ }^{1}$, \\ MICHAEL TINGGI ${ }^{1}$ \\ ${ }^{1}$ Faculty of Economics and Business, UNIVERSITI MALAYSIA SARAWAK, MALAYSIA. \\ ${ }^{2}$ School of Management, UNIVERSITI SAINS MALAYSIA, MALAYSIA \\ ${ }^{3}$ Graduate School of Business, UNIVERSITI SAINS MALAYSIA, MALAYSIA \\ *E-mail: ccssharon@unimas.my
}

\begin{abstract}
Malaysian charities have been reported to face problems in raising funds in the face of the current challenging economic environment. Some evidence has been provided by past research, in for-profit organisations, on the influence of accountability, financial management capacity, own income generation and revenue diversification on financial performance. This study examines their impact on non-profit financial sustainability, utilising as sample 212 active charities in 2017. The quantitative approach is adopted whereby data on financial management capacity, accountability, own income generation and revenue diversification, and their inter-relationships, were tested for strength and influence of the relationships, if any, with financial sustainability. Analysis of data was performed using the structural equation modeling method using lavaan on R. Global fit values (RMSEA $=0.00 ;$ SRMR $=0.04$ ) showed a good model fit and standardised residuals justified retaining the model at the pairing levels of the observed variables; as such the original model is retained and not respecified. The findings suggest positive and significant indirect relationships between financial management capacity and accountability with the financial sustainability, as mediated by revenue diversification and own income generation. The implications and contributions arising from the findings are also discussed.
\end{abstract}

Keywords: financial sustainability, financial management capacity, accountability, own income generation, revenue diversification, charities, Malaysia

JEL Classification: C1, L2 


\section{Introduction}

Charities are an important element of the economy and social infrastructure (OECD, 1995; Salamon and Anheier, 1997; Abraham, 2003) and play diverse roles ranging from being human services provider, an agent of social innovation and change and a significant employment source (Simsa, Rausher, Schbober and Moder, 2014). The provision of human services, such as health and education, contributes to general societal well-being and quality of life (Enjolras and Sivesind, 2018). Such services fill the gaps in those provided by the government (Abraham, 2003; Enjolras and Sivesind, 2018). Yet, in Malaysia, charities have been reported to face problems in raising funds (Wong, 2016; Foo and Mohd Rani, 2017). For charities to continue playing their roles, they need to be financially sustainable in the long term. This is all the more important in the current challenging economic environment whereby funds, in the form of public or governmental support are largely limited. Therefore, this study aims to investigate the factors that could have an impact on charity financial sustainability, either directly or indirectly, on charity financial sustainability, in particular financial management capacity, accountability, own income generation and revenue diversification.

\section{Theoretical basis for the study and literature review}

\subsection{Financial management capacity and financial sustainability}

Literature that has tested the link between sound financial management with financial sustainability were largely related to attempts to predict the financial distress or failure of non-profit organisations. Such studies identified ratios that represent solvency, profitability, leverage, cash flow and cost ratios, and operational efficiency, amongst others (Ohlson, 1980; Chabotar, 1989; Tuckman and Chang, 1991; Greenlee and Trussel, 2000; Grove and Basilico, 2008; Copps and Vernon, 2010; Ryan and Irvine, 2012; Atan, Zainon, Aliman, and Nam, 2013; Midot, 2013; Omar, Arshad, and Razali, 2013; Tevel, Katz, and Brock, 2014).

In terms of financial management practices in non-profits, Waiganjo, Ng'ethe and Mugambi (2012), Ali (2012), Njoroge (2013) and Saungweme (2014) noted a strong positive relationship between sound financial practices and processes with financial sustainability. Lewis (2011), Ali (2012) and Ebrahim (2005) in particular noted that such sound practices were instrumental in helping non-profits carry out their mandate to stakeholders and attain their objectives, and help to convince donors that donated monies would be used for planned (and not other) purposes (Lewis, 2011; Okorley, Deh and Owusu, 2012). In the case of public universities in Malaysia, Nik Ahmad, Ismail and Siraj (2019) noted the importance of the full utilisation of resources in aiding financial sustainability.

Literature pertaining to non-profits have largely concurred that financial management capacity is positively related to financial sustainability. However, the studies linking financial management ratios to financial sustainability have assumed the said link as the former was used as a predictor for the latter. The studies investigating the impact of financial management practices and processes on financial sustainability employed data collected either via qualitative case studies, and questionnaires or in-depth administered to informants from non-profit organisations (Ali, 2012; Okorley et al., 2012; Waiganjo et al., 2012; Njoroge, 2013; Saungweme, 2014; Nik Ahmad et.al, 2019); as such, only the opinions and perceptions of individuals within the organisations were obtained and objective secondary data was not empirically tested.

None of the studies reviewed considered financial management capacity from the perspective of the professional qualifications of the non-profit accounting and finance personnel. This study argues that eventhough current practices and state of financial health are important, professional qualifications of finance personnel are equally, if not more, important, as professionally qualified persons are theoretically 
and practically trained in the necessary skills and competences. Also, to maintain an active professional membership, they will need to ensure that they receive the necessary technical updates. Hence, it is argued that the existence of professional qualifications amongst the accountants or finance personnel of charities is a more comprehensive measurement of financial management capacity than financial health or financial practices (which both represent the current state of affairs), as it has implications on the future state of the said charities.

Hence, Hypothesis 1 is proposed:

Financial management capacity has a positive and direct relationship with financial sustainability in Malaysian charities.

\subsection{Financial management capacity, own income generation, revenue diversification and financial sustainability}

The link between financial management capacity and financial sustainability has been discussed in the previous section. However, it is postulated that the link is not only a direct one but also connected via mediating variables, in particular revenue diversification and own income generation. Financial management, revenue diversification and own income generation are closely linked in corporate finance literature. Diversification reduces the unsystematic risk that a single investment performs differently than expected (Brealey and Myers, 1991). This concept is also practised in government finance, where revenue diversification is often recommended as a strategy for effective fiscal management (Carroll, 2009). In this context, revenue structures are diversified to decrease the instability of the overall tax structure (White, 1983) and ensure better preparedness for fiscal crises (Shannon, 1987).

Financial management has been noted to drive revenue diversification and own income generation in the non-profit context. For instance, von Schnurbein and Fritz (2017) noted the driving of revenue diversification by professionalisation, which encompasses the managing and controlling resources, financial management and accounting. Crowther (2017) found that a formulation of a sustainable financial management strategy included the expansion of services to generate additional sources of income, other than that already generated mainstream (own income generation). This is supported by Parker (2003) who found links between financial management strategy and revenue diversification and own income generation in his qualitative study on a non-profit community welfare organisation in Australia. Peterson (1986) in his study of cultural organisations noted that revenue-generating activities which are ancillary to the main activity foster a cost-benefit mentality, an important feature of good financial management. Ko and Liu (2020) found that incorporation of commercial processes were done to generate more revenue streams in traditional nonprofit organisations, thereby transforming such organisations into social enterprises.

From the perspective of human resource capacity (to carry out effective financial management), DiMaggio (1986) and Adams and Perlmutter (1991) respectively found links between an increase in professional staff and the replacement of socially-focused staff with business-oriented individuals and higher levels of earned income. At the same time, the practice of financial management has been found to drive commercial sources of income (Crowther, 2017). In other words, there is support for a correlation between financial management capacity and own income generation. A non-profit's default method for raising funds would be to collect donations and contributions, therefore a non-profit that attempts to generate its own income commercially would automatically be engaging in revenue diversification.

Revenue diversification would then lead to financial sustainability. Empirical evidence has noted that revenue diversification led to greater revenue and financial stability (Froelich, 1999; Carroll and Stater, 2009), as every revenue source had specific characteristics (positive and negative) from the perspective of volatility, organisational goal displacement and effects on processes and structures. Chang and Tuckman 
(1994) noted that revenue diversification encouraged financial position strength. A study on private colleges and universities (Webb, 2015) noted that increasing revenue diversification in the years preceding recession resulted in greater year-over-year total revenue per student. Foster and Meinhard (2000) noted the adoption of revenue diversification strategies to support program delivery amongst voluntary organisations in Canada. Kim (2014) noted that revenue diversification was associated with greater attendance numbers amongst nonprofit arts and cultural organisations, although the results were largely dependent on how the diversification was operationalised. Ahmad, Ng and Ting (2015) and Zaharuddin, Zakaria and Zakaria (2018) noted that commercialisation leads to sustainable funding. Ochieng (2016) noted that expansion of subsidising sources, amongst other factors, contributed generally to the budgetary supportability of NGOs in Kenya. This was supported by Nyanumba, Rotich, Gekara, Keraro, and Okari (2017) and Mohamed and Muturi (2017) who conducted studies on the performance of counties and local non-governmental organisations in Kenya respectively. However, studies have also shown no correlation between revenue diversification and financial sustainability (e.g. Scurto-Davis, 2014, for nonprofit arts organisations; Lin, 2010; Singh and Mofokeng, 2014). Singh and Mofokeng (2014), in particular, noted that revenue diversification in itself does not necessarily ensure financial sustainability as striking the correct balance of revenue sources was a challenge. Another study on small NGOs serving the subSaharan Africa (Despard, Adjabeng and Nafziger-Mayegun, 2016), observed that revenue diversification was even associated with inadequate financial reserves and lack of funding, leading to service reduction; this led them to conclude that procurement of reliable financial resources was a complex challenge. Chikoto and Neely (2014) noted that revenue concentration (and not diversification) led to financial growth and increased financial capacity.

In view of the foregoing, it is postulated that:

Hypothesis 2: Own income generation and revenue diversification jointly mediate the relationship between financial management capacity and financial sustainability in Malaysian charities

\subsection{Accountability, revenue diversification and financial sustainability}

There is a lacunae of studies in the non-profit context examining accountability and financial sustainability. Abraham (2003) proposed a model linking financial accountability, in the form of effective accounting systems and responsible financial management, with financial sustainability for non-profit organisations (NPO), to determine an NPO's financial health based on various operational criteria. Arshad et al. (2013) noted that the ability of a NPO to be accountable is decreased due to financial vulnerability. Governance, a concept close to accountability, has been noted to be related to organisational efficiency (Callen, Klein and Tinkelman, 2003; Alexander and Lee, 2006) and performance (Betzler and Gmür, 2012).

Accountability has been noted to be positively associated with the gaining of other resources (Zimmerman and Zeitz, 2002) and was further theorised to predict revenue diversification (Chikoto and Neely, 2014). This was conceptualised by Keating and Frumkin (2003) in their financial reporting system feedback model in which the user community (donors and clients) decide whether to participate or support a non-profit organisation based on information disclosed by the management of the said organisation. Zhu, Ye and Liu (2018) confirmed this relationship in their empirical study on grassroots NGOs in China; they noted that stakeholder accountability leads to legitimacy (Black, 2008), and resource providers will then contribute funding based on that legitimacy (Galaskiewicz and Bielefeld, 1998).

Revenue diversification has also been noted to be a precursor to greater accountability. Revenue diversification implies raising funds from a variety of sources: government agencies, corporations, foundation donors and commercial undertakings. Literature has shown that certain revenue strategies entail different levels of accountability (Froelich, 1999). For instance, procurement of government funding would subject the non-profit to complicated government rules and regulations, standardised 
documentation, evaluation and accountability (Nielsen, 1979; Peterson, 1986; Gronbjerg, 1991, 1992, 1993), whereby non-profits lacking in such procedures would find difficulty in accessing government funds.

Corporate and foundation donors are also now more professionalised such that more formalised procedures are involved in the giving process, involving contribution officers and committees (DiMaggio, 1986; Kelly, 1998; Peterson, 1986; Useem, 1987). Their influence on organisation accountability includes the requirement of mission statements and the usage of efficiency and effectiveness measures, as well as the inclusion of corporate board members as non-profit directors, which further reinforces the increase in accountability (Kelly, 1998; Peterson, 1986; Useem, 1987).

There is also support that commercialisation of activities brings about greater accountability. For instance, Peterson (1986) found that secondary activities which generate commercial income cultivate more prudent accountability practices. Powell and Owen-Smith (1998) also noted that increasing commercialisation led to an increase in management and administrative effort, together with expansion of internal governance mechanisms.

In view of the foregoing, Powell and Friedkin (1987) summarised that the pursuance of revenue diversification can lead to greater levels of organisational formality and professionalism, both of which are aspects of accountability.

It can be seen from the preceding paragraphs, that accountability could cause revenue diversification and also vice versa. However, it has also been implied that there could be an inverse relationship between accountability and revenue diversification. Reed and Howe (1999) and Young and Salamon (2002) noted that the commercialisation of non-profits (and hence revenue diversification) was embarked upon due to the increased demands for accountability by donors, amongst other factors (such as limited revenue streams, increased demand for services, increased competition from similar service providers, greater availability of corporate partners, the challenge of finding and utilising volunteers and growing concerns about liability. In other words, non-profit organisations are driven to embrace revenue diversification and commercialisation to avoid having to be accountable to charitable donors.

In summary, literature would support the causation of accountability by revenue diversification; it also supports the causation of revenue diversification by accountability. Some literature also indicated an inverse relationship.

Hence, the proposed hypothesis is as follows:

Hypothesis 3: Revenue diversification mediates the relationship between accountability and financial sustainability in Malaysian charities.

\subsection{Theoretical framework and underlying theory}

In view of the foregoing, the theoretical framework for this study is as follows:

Figure 1 Theoretical framework of this study

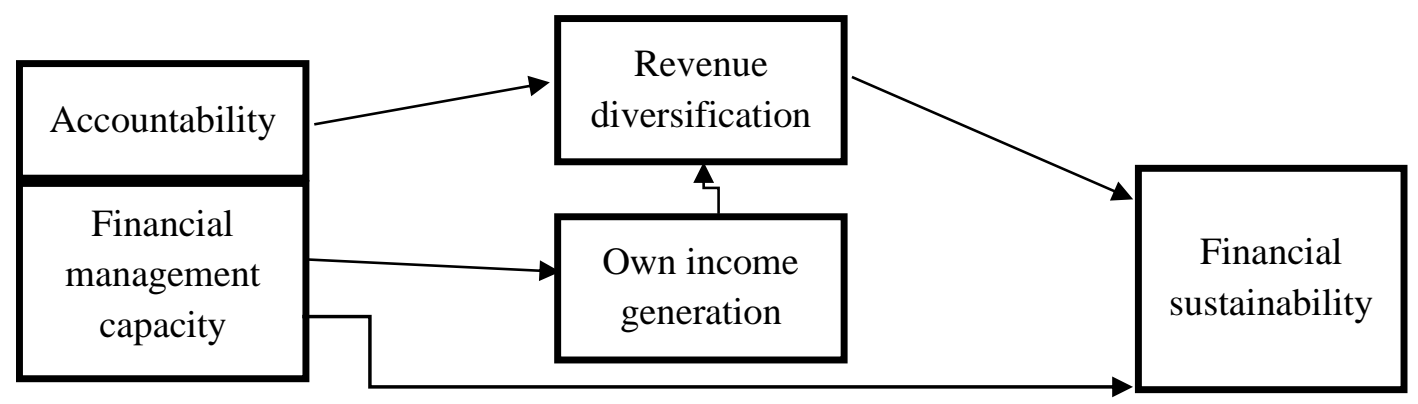


This framework, incorporating the independent, intervening and dependent variables, is newly created and has never been collectively studied. This study utilises both stewardship theory and resource dependency theory to explain the framework. Both theories explain the actions and decisions of directors in the process of achieving financial sustainability.

According to the resource dependency theory (RDT), an organisation is dependent on external resources in its environment (Brettel and Voss, 2013; Pfeffer and Salancik, 2003). Hence its survival relies on its management of the flow of (scarce) resources and the ability to reduce uncertainty in its environment (Pfeffer and Salancik, 1978), in order to achieve financial sustainability. The directors would manage the internal resources and obtain external resources via financial management capacity, own income generation and revenue diversification.

The stewardship theory (Muth \& Donaldson, 1998) posits that managers, left on their own, will act as responsible stewards of the assets they control. Therefore, directors would practise accountability and ensure good financial management capacity to steward the assets under their control.

\section{Methodology}

The sample of the study is a total of 212 companies limited by guarantee (CLBG) in Malaysia which submitted financial statements and annual returns in the year 2017. Companies limited by guarantee are essentially non-profit entities whereby shareholders do not put up funds as investment; rather, its members undertake to contribute to the assets of the company if the company is wound up. Data is extracted from financial statements and the database maintained by the Companies Commission of Malaysia. The sample excluded CLBGs that were dormant, that failed to submit financial statements in 2017, with only a year of operations and/or whose financial statements were prepared on a break-up basis. Excluded also were CLBGs which did not have any element of public benefit as their objectives.

In this study, financial sustainability is measured as solvency, which is the opposite of insolvency risk as one measure of financial vulnerability (Keating, Fischer, Gordon and Greenlee, 2005). Solvency refers to the ability to repay liabilities when due and is coded as 1 if assets exceed liabilities and 0 otherwise.

For accountability, the study adopted the approach by Yasmin et al. (2014), which considered 4 accountability aspects: probity or legality, process, performance, programme and policy, and adapted the same to the Malaysian environment. These aspects form part of an overall accountability index; they are measured accordingly and equally weighted within the said index in line with Chow and Wong-Boren (1987). Details of the accountability perspectives, items tested, source of information, measurement, weightage and scoring can be obtained separately from the author.

Financial management capacity is measured by reference to existence of professionally qualified accountants on the board of directors or trustees. A numerical score of 'one' is given for every director or trustee who is a Malaysian Institute of Accountants (MIA) member. Determination as to whether a director/trustee is a MIA member is made via a membership search on the MIA website.

Before revenue diversification is measured, revenue concentration (its opposite) is first calculated. Revenue concentration is measured with the Herf index that examines two aspects: the quantity of diverse revenue sources and the degree to which these revenues are equally distributed (Yan, Denison and Butler, 2009; Calabrese, 2012; Wicker, Feiler and Bruer, 2013; Chikoto and Neely, 2014). The Herf index is the sum of the squared proportions of all revenue sources of the organization and is calculated as follows:

$$
\text { Herf }=\sum_{i=\mathbf{1}}^{n}\left(\mathbf{r}_{\overline{\mathbf{i}}} / \mathbf{R e v}\right)^{2}, i=\mathbf{1} \ldots n
$$

Whereby $r=$ revenue source, $\operatorname{Rev}=$ total revenue, $n=$ number of revenues 
Revenue diversification would be expressed as 1 - Herf, perfect concentration would return a value of 0 ; in other words, the organization has only one income source. Perfect diversification (which does not exist) would return a value of 1 . Information for the calculation of revenue diversification is obtained from the financial statements of the charity.

Own income generation is measured using the proportion of commercial revenue of total revenue. In this study, commercial revenue comprises proceeds from sales of goods and services, in line with Keating et al. (2005). A charity which does not have any commercial revenue would therefore return a value of zero for this measure.

Information for the calculation of revenue diversification and scoring of own income generation is extracted from the charity financial statements.

For testing the hypotheses $\mathrm{H} 1$ to $\mathrm{H} 3$, structural equation modelling (SEM) is used to evaluate and confirm the proposed model. SEM is utilised as it is able to deal with a system of regression equations and hence model complex dependencies, which the theoretical framework entails. The software R package together with the ancillary packages lavaan and Piecewise SEM are utilised (Rosseel, 2012).

\section{Results and discussion}

\subsection{Data distribution and missing data}

All data was manually collected via content analysis of financial statements and other relevant documents. The process of data collection included ensuring that there were no missing values. Hence, no missing values were noted in the data.

For financial sustainability (measured in solvency), 66.04\% of the 212 charities analysed showed positive solvency. As the dependent variable is dichotomous, the score is 0 when a charity is deemed insolvent (asset are less than liabilities) and code as 1 when the converse occurs.

Descriptive analysis of the other variables accountability, financial management capacity, revenue diversification and own income generation are detailed in Table 1 below:

Table 1 Descriptive analysis of accountability, financial management capacity, revenue diversification and own income generation

\begin{tabular}{|l|c|c|c|c|c|c|c|c|}
\hline \multicolumn{1}{|c|}{ Variable } & Data type & $\begin{array}{c}\text { No. of } \\
\text { observations }\end{array}$ & Mean & $\begin{array}{c}\text { Standard } \\
\text { deviation }\end{array}$ & Min & Max & Skewness & Kurtosis \\
\hline Accountabi-lity & Ratio & 212 & 0.141 & 0.114 & -.307 & 0.606 & 0.718 & 5.822 \\
\hline $\begin{array}{l}\text { Financial } \\
\text { management } \\
\text { capacity }\end{array}$ & $\begin{array}{l}\text { Ratio \& } \\
\text { discrete }\end{array}$ & 212 & 0.175 & 0.416 & 0 & 2 & N/A & N/A \\
\hline $\begin{array}{l}\text { Revenue } \\
\text { diversifica-tion }\end{array}$ & Ratio & 212 & 0.101 & 0.180 & 0 & 0.766 & 1.692 & 4.813 \\
\hline $\begin{array}{l}\text { Own income } \\
\text { generation }\end{array}$ & Ratio & 212 & 0.289 & 0.416 & 0 & 1 & N/A & N/A \\
\hline
\end{tabular}

The average accountability score appears to be low in general, due mainly to poor internal and external timeliness in financial statement submission to the Companies Commission of Malaysia. A moderate positive skewness $(+0.718)$ and high kurtosis of 5.822 (more than 3 ) are noted, indicating a leptokurtic distribution.

For financial management capacity, the maximum value is 2 , meaning that the maximum number of directors in a charity with the MIA qualification is 2; while the minimum value is zero, indicating zero directors with the said qualification. The mean of 0.175 appears low in view of the fact that the maximum 
value is 2 . The distribution is skewed to the right with the mode being at value zero. This means that a large number of charities have no directors who are MIA-qualified.

The mean value of revenue diversification appears low in view of the fact that the maximum achievable score is 1 . Distribution is highly skewed to the right $(+1.692)$, indicating that a larger proportion of charities have revenue diversification scores greater than the mean. However, the disproportionately high bar for the value zero indicates that there are also many charities with no revenue diversification (in other words, having just one source of income). The minimum score of 0 indicates the lack of diversification; in other words, the charity only has one revenue source. The maximum score of 0.766 indicates a high level of revenue diversification, whereby the organisation has a number of revenue sources of comparable magnitude.

Own income generation also appears low in view of the fact that the maximum achievable score is 1 . The distribution is bimodal with high values at the two extremes, which means that charities either largely depend wholly on donation and donation-related receipts (with minimum value of 0 ), or on wholly commercially-generated income (with maximum value of 1 ). The extreme left side of the histogram is significantly higher than the extreme right, indicating that more charities rely on donations only compared to those that generate their own income.

From the foregoing, the multivariate data is largely non-normal in distribution; this was confirmed by various tests for multivariate normality, such as Doornik and Hansen (2008), Mardia (1970), Henze and Zirkler (1990) which all returned $p$ values less than 0.05 , implying that the distribution of the data is not significantly different from normal distribution. In other words, data normality cannot be assumed. Data non-normality is addressed by the use of the (robust) Diagonally Weighted Least Squares (DWLS) estimation procedure when performing SEM, which is supported by Mîndrilă (2010), DiStefano and Morgan (2014), and Muthén, du Toit and Spisic (1997).

\subsection{Model specification and identification}

The structural equation modelling application in this study is strictly confirmatory. The literature review has led to an a priori model specification presented in Figure 1. The equations are as follows:

$$
\begin{aligned}
& \text { Equation (1): } \begin{array}{l}
\text { Financial sustainability }=\alpha+\beta_{1} \text { Revenue diversification }+\beta_{2} \text { Financial } \\
\text { management capacity }+\mathrm{e}_{1}
\end{array} \\
& \begin{aligned}
\text { Equation (2): } & \text { Revenue diversification }=\mu+\beta_{3} \text { Accountability }+\beta_{4} \text { Own income generation } \\
& +\mathrm{e}_{2}
\end{aligned} \\
& \text { Equation (3): } \quad \text { Own income generation }=\lambda+\beta_{5} \text { Financial management capacity }+\mathrm{e}_{3} \\
& \text { Where } \alpha, \mu, \lambda, \nu=\text { Constants, } \beta_{1^{-}{ }^{-}}=\text {Coefficients of beta, and } \mathrm{e}_{1^{-} 3}=\text { error terms }
\end{aligned}
$$

The study model does not have a measurement model component as all variables are directly observed (there are no latent variables). As all paths are directionally one-way and causation move towards one direction, hence the model is recursive. All pathways in the model are left free to be estimated; no relationships nor parameters are set as fixed or constrained. The total number of free parameters is 10 ( 5 observed variable variances and 5 path coefficients); the number of observations for the model is 15 [0.5 $x k(k+1)$, where $k=5]$.

Interaction effects in the model refer to the interaction between Accountability and Revenue diversification, and amongst Financial Management Capacity, Own Income Generation and Revenue diversification, in leading to Financial Sustainability.

The study model is also identified based on the order and rank conditions. The order condition is a necessary condition, but it is by itself not sufficient. For every equation under consideration, the number 
of all variables in the model excluded from the equation $(\mathrm{k})$ must be equal or more than the number of endogenous variables $(\mathrm{m})$ in the model less one. In other words, $\mathrm{k} \geq \mathrm{m}-1$ must be true for every equation. For the study model, the total number of endogenous variables is 3 (Financial sustainability, Revenue diversification and Own income generation). Equations (1) - (2) all have 2 excluded variables while Equation (3) has 3 . Therefore the $k \geq m-1$ condition is met and the said equations are either exactly or over-identified. Hence, the order condition is met.

The rank condition is a necessary and sufficient condition which states that all equations must be linearly independent of each other. In a system of $\mathrm{G}$ equations, the rank of the matrix of parameters of all the excluded variables from an equation must be equal to (G-1). The study model has 3 equations, and hence (G-1) equals 2 . A matrix for each equation is set up where included variables are marked with a " 1 " and excluded variables are marked with a " 0 ", as showed in Table 2 below:

Table 2 Matrix for each equation in the study

\begin{tabular}{|l|c|c|c|c|c|}
\hline $\begin{array}{c}\text { Equation/ } \\
\text { Variable }\end{array}$ & $\begin{array}{c}\text { Financial } \\
\text { sustainability }\end{array}$ & $\begin{array}{c}\text { Revenue } \\
\text { diversification }\end{array}$ & Accountability & $\begin{array}{c}\text { Financial } \\
\text { management } \\
\text { capacity }\end{array}$ & $\begin{array}{c}\text { Own income } \\
\text { generation }\end{array}$ \\
\hline Equation(1) & 1 & 1 & 0 & 0 & 1 \\
\hline Equation(2) & 0 & 1 & 1 & 1 & 0 \\
\hline Equation(3) & 0 & 0 & 0 & 1 & 1 \\
\hline
\end{tabular}

The rank of the matrix for the parameters of all excluded variables for each equation is 2 , hence the rank condition is met.

Estimation method used was diagonally weighted least squares (DWLS) as it is able to handle a nonnormal data distribution as well as dichotomous variables. No adjustments needed to be made to the default criteria in the software to achieve convergence. Results are estimated for 3 models which differ by the measurement of financial sustainability. For all models estimated, there were no inadmissible results such as error variances of less than zero or proportions of explained variance exceeding 1.

The software lavaan package version 0.6-6 in R version 3.6.1 (Rosseel, 2012) was used in the data analysis, and the estimator used is Diagonally Weighted Least Squares) as it is robust and suitable for a non-normal data distribution (as recommended by Mîndrilă (2010)). There were no inadmissible solutions. A global estimation approach was taken whereby the relationships between all variables are estimated at once instead of in stages.

The results converged after 30 iterations without the need for any adjustment. Table 3 below shows the estimation results for direct effects. 
Table 3 Estimation results for direct effects

\begin{tabular}{|c|c|c|c|c|c|c|c|}
\hline \multicolumn{8}{|c|}{ Direct effects } \\
\hline Hypotheses & Relationship & Estimate & $\begin{array}{l}\text { Standardised } \\
\text { estimate }\end{array}$ & $\begin{array}{l}\text { Standard } \\
\text { error }\end{array}$ & z-value & $P(>|z|)$ & Supported? \\
\hline 1 & $\begin{array}{c}\text { Financial } \\
\text { management } \\
\text { capacity } \rightarrow \\
\text { Financial } \\
\text { sustainability }\end{array}$ & 0.186 & 0.076 & 0.242 & 0.769 & 0.442 & NO \\
\hline 2 (part) & $\begin{array}{c}\text { Financial } \\
\text { management } \\
\text { capacity } \rightarrow \text { Own } \\
\text { income generation }\end{array}$ & 0.182 & 0.180 & 0.084 & 2.162 & $0.031 * *$ & YES \\
\hline 2 (part) & $\begin{array}{l}\text { Own income } \\
\text { generation } \rightarrow \\
\text { Revenue } \\
\text { diversification }\end{array}$ & 0.170 & 0.400 & 0.038 & 4.480 & $0.000 *$ & YES \\
\hline 3 (part) & $\begin{array}{c}\text { Accountability } \rightarrow \\
\text { Revenue } \\
\text { diversification }\end{array}$ & 0.449 & 0.289 & 0.095 & 4.717 & $0.000 *$ & YES \\
\hline 2,3 (parts) & $\begin{array}{c}\text { Revenue } \\
\text { diversification } \\
\rightarrow \text { Financial } \\
\text { sustainability }\end{array}$ & 3.17 & 0.549 & 0.484 & 6.552 & $0.000 *$ & YES \\
\hline
\end{tabular}

The estimation results show that Hypotheses 2 and 3 are supported, but not Hypothesis 1 . All direct paths that are determined to be significant (either at $p<0.001$ or 0.05 ) have expected positive coefficients.

At this point, the general mediation approach of this study is discussed. Firstly, the direct effects between each variable are examined to determine the plausibility of the entire model, in line with Judd and Kenny (1981), James and Brett (1984) and Baron and Kenny (1986). Secondly, the mediating effects are examined. This study adopts the product of coefficients approach (Mackinnon et al., 2007) as it maintains good Type I error and power rates, with bootstrapping utilised to construct confidence intervals for the indirect effects (Preacher and Hayes, 2004). The bias-corrected and accelerated bootstrap is used because it does not assume normality of data distribution (Hair, Hult, Ringle and Sarstedt, 2014; Pardo and Roman, 2013), and adjusts for both bias and skewness in the bootstrap distribution (Efron, 1987). The details of the estimation results for indirect effects are disclosed in Table 4 below, and the findings are noted to be consistent with that of Table 3 . 
Financial Management Capacity, Accountability, Own Income Generation, Revenue Diversification and Financial Sustainability in Charities of Malaysia

Table 4 Estimation results for indirect effects

\begin{tabular}{|c|c|c|c|c|c|c|c|c|c|}
\hline \multicolumn{10}{|c|}{ Indirect effects } \\
\hline Hypotheses & Relationship & Estimate & $\begin{array}{l}\text { Stand-ardi-sed } \\
\text { estimate }\end{array}$ & $\begin{array}{c}\text { Stan-dard } \\
\text { error }\end{array}$ & z-value & $P(>|z|)$ & $\begin{array}{c}\text { Confidence } \\
\text { interval } \\
\text { (lower) }\end{array}$ & $\begin{array}{c}\text { Confidence } \\
\text { interval } \\
\text { (upper) }\end{array}$ & Supported? \\
\hline 2 & $\begin{array}{c}\text { Financial } \\
\text { management } \\
\text { capacity } \rightarrow \text { Own } \\
\text { income generation } \\
\rightarrow \text { Revenue } \\
\text { diversification } \rightarrow \\
\text { Financial } \\
\text { sustainability }\end{array}$ & 0.098 & 0.040 & 0.061 & 1.609 & 0.108 & 0.016 & 0.256 & YES \\
\hline 3 & $\begin{array}{c}\text { Accountability } \rightarrow \\
\text { Revenue } \\
\text { diversification } \rightarrow \\
\text { Financial } \\
\text { sustainability }\end{array}$ & 1.423 & 0.159 & 0.587 & 2.423 & 0.015 & 0.452 & 2.746 & YES \\
\hline
\end{tabular}

\subsection{Model fit}

The following Table 5 presents the global fit measures for the estimated study model.

Table 5 Global fit measures for estimated model of this study

\begin{tabular}{|c|c|c|}
\hline Fit measure & Benchmark \& reference & Result \\
\hline $\begin{array}{l}\text { Root Mean Square } \\
\text { Error of } \\
\text { Approximation } \\
\text { (RMSEA) }\end{array}$ & $\begin{array}{c}\text { Cut-off value }=0.06 \\
\text { (Hu and Bentler, 1999) } \\
\text { Lower confidence limit }=0 \text { and higher confidence } \\
\text { limit }<0.08 \\
\text { (MacCallum, Browne, and Sugawara, 1996; } \\
\text { McQuitty, 2004) }\end{array}$ & $\begin{array}{c}0.000 \text { (Upper } \\
\text { confidence level = } \\
0.000 ; \\
\text { lower confidence } \\
\text { interval = 0.071) }\end{array}$ \\
\hline Goodness-of-Fit (GFI) & $\begin{array}{l}\text { Cut-off value }=0.95 \text {, the higher the better } \\
\text { (Miles and Shevlin, 1998) }\end{array}$ & 0.987 \\
\hline $\begin{array}{l}\text { Adjusted Goodness- } \\
\text { of-Fit (AGFI) }\end{array}$ & $\begin{array}{c}>0.90 \\
\text { (Hooper, Coughlan and Mullen, 2008) }\end{array}$ & 0.955 \\
\hline $\begin{array}{l}\text { Standardized Root } \\
\text { Mean Square Residual } \\
\text { (SRMR) }\end{array}$ & $\begin{array}{l}\text { Cut-off value }=0.08, \text { the lower the better } \\
\qquad \text { (Hu and Bentler, 1999) }\end{array}$ & 0.040 \\
\hline $\begin{array}{l}\text { Non-Normed Fit Index } \\
\text { (NNFI) }\end{array}$ & $\begin{array}{l}\text { Cut-off value }=0.95 \text {, the higher the better } \\
\qquad \text { (Hu and Bentler, 1999) }\end{array}$ & 1.038 \\
\hline $\begin{array}{l}\text { Comparative Fit Index } \\
\text { (CFI) }\end{array}$ & $\geq 0.95$ (Hu and Bentler, 1999) & 1.000 \\
\hline
\end{tabular}

Based on the fit measure results, the proposed model appears to show a high level of fit, and as such, no post-hoc modifications needed to be conducted. 
A review of the residual matrices for the model was performed and none of the residual values exceed 0.1 ; this hence justifies retaining the model at the pairing levels of observed variables.

\section{Discussion and conclusion}

Based on the findings, financial management capacity has a relationship with financial sustainability; however, the relationship is not direct (as Hypothesis 1 is disproved) but indirect and mediated by own income generation and revenue diversification (Hypothesis 2). The literature recognises that financial management, own income generation and revenue diversification are strongly interlinked. Revenue diversification is an effective financial management strategy as it reduces the risk of depending on a sole revenue source (White, 1983; Brealey and Myers, 1991; Carroll, 2009; von Schnurbein and Fritz, 2017). At the same time, sustainable financial management strategy formulation is linked to the generation of additional sources of income (Peterson, 1986; Crowther, 2017) as well as generation of commercial income (DiMaggio, 1986; Adams and Perlmutter, 1991), and Parker (2003) noted links between all three variables in one study. Hence the findings of this study support the empirical literature.

Accountability also has a positive and significant indirect relationship with financial sustainability as mediated by revenue diversification (Hypothesis 3). As mentioned in literature, a possible reason for this is due to the organisational legitimacy offered by accountability (Black, 2008), and resource providers will contribute capital based on their perception of this (Galaskiewicz and Bielefeld, 1998). There would also be an increase in the number of revenue streams as a result of greater legitimacy (Zhu, Ye and Liu, 2018). The combined effect of increased revenue magnitude and number of revenue streams leads to increased financial sustainability.

As financial management capacity has been proven to have an impact on charity financial sustainability, the clear implication from this is that charities should endeavour to recruit directors with accounting professional qualifications as the latter is a reliable indication of financial skills and competence, as well as ethical behaviour. This study has also proven a link between accountability and financial sustainability. As such, more provisions in non-profit and third sector laws and regulations pertaining to governance are recommended.

The study's main limitation is that the data used for analysis is cross-sectional, and hence the information captured is for a single point in time. Two issues arise from this: the data may not be population-representative, and causation and effect cannot be determined. Hence, future research could make use of time series data, utilising more robust econometric analytical techniques.

Acknowledgement: This work was fully funded by Research Grant No. F01/SpMYRA/1689/2018 from Universiti Malaysia Sarawak. 


\section{Referencias}

1. Abraham, A. (2003). Financial sustainability and accountability: a model for nonprofit organisations. In AFAANZ 2003 Conference Proceedings. Brisbane, Australia: AFAANZ. Retrieved from http://ro.uow.edu.au/commpapers/739/

2. Adams, C., \& Perlmutter, F. (1991). Commercial venturing and the transformation of America's voluntary social welfare agencies. Nonprofit and Voluntary Sector Quarterly, 20, 25-38.

3. Ahmad, A.R., Ng, K.S. and Ting, N.P. (2015). Income Generation Activities among Academic Staffs at Malaysian Public Universities. International Education Studies, 8(6), 194-203.

4. Alexander, J. A., \& Lee, S.-Y. D. (2006). Does Governance Matter? Board Configuration and Performance in Not-for-Profit Hospitals. Milbank Quarterly, 84(4), 733-758.

5. Ali, A.A. (2012). Factors influencing sustainable funding of non-governmental organisations in Kenya: A case study of Sisters Maternity Home (SIMANO) in Garissa. Nairobi University, Kenya.

6. Arshad, R., Abu Bakar, N., Wan Mohd Razali, W. A. A., \& Omar, N. (2013). Financial Vulnerability, Risk Management and Accountability of Non-Profit Organisations. Journal of Energy Technologies and Policy, 3(11), 408-414.

7. Atan, R., Zainon, S., Aliman, S., \& Nam, R. Y. T. (2013). Financial Management in Religious Non-Profit (pp. 502-505). Presented at the International Conference on Advanced Computer Science and Electronics Information (ICACSEI 2013), Beijing, China: Atlantis Press. Retrieved from http://www.atlantis-press.com/php/download_paper.php?id=7602

8. Baron, R.M. and Kenny, D.A. (1986). The moderator-mediator variable distinction in social psychological research: Conceptual, strategic, and statistical considerations. Journal of Personality and Social Psychology, 51, 1173-1182.

9. Betzler, D., \& Gmür, M. (2012). Towards fund-raising excellence in museums-linking governance with performance: Towards fund-raising excellence in museums. International Journal of Nonprofit and Voluntary Sector Marketing, 17(3), 275-292. http://doi.org/10.1002/nvsm.1429

10.Black, J. (2008). Constructing and contesting legitimacy and accountability in polycentric regulatory regimes. Regulation and Governance, 2(2), 137-164.

11.Brealey, R. A. and Myers, S. C. (1991). Principles of Corporate Finance (4th Ed). McGraw-Hill, Inc.

12. Brettel, M. and Voss, U. (2013). Antecedents of Management Control Combinations -An Explanation from Resource Dependence Theory. Schmalenbach Business Review, 65 (October), 409-430.

13.Calabrese, T. (2012). The accumulation of nonprofit profits: A dynamic analysis. Nonprofit and Voluntary Sector Quarterly, 41(2), 300-324.

14.Callen, J.L., Klein, A., \& Tinkelman, D. (2003). Board Composition, Committees, and Organizational Efficiency: The Case of Nonprofits. Nonprofit and Voluntary Sector Quarterly, 32(4), 493-520. http://doi.org/10.1177/0899764003257462

15.Carroll, D. A., \& Stater, K. J. (2009). Revenue Diversification in Nonprofit Organizations: Does it Lead to Financial Stability? Journal of Public Administration Research and Theory, 19(4), 947-966. https://doi.org/10.1093/jopart/mun025

16.Carroll, D.A. (2009). Diversifying Municipal Government Revenue Structures: Fiscal Illusion or Instability? Public Budgeting \& Finance, 29(1), 27-48.

17. Chabotar, K.J. (1989). Financial Ratio Analysis Comes to Nonprofits. Journal of Higher Education, 60 (2), 188-208. 
18.Chang, C.F. \& Tuckman, H.P. (1994) Voluntas: International Journal of Voluntary and Nonprofit Organizations, 5(3), 273-290.

19.Chikoto, G. L., \& Neely, D. G. (2014). Building nonprofit financial capacity: The impact of revenue concentration and overhead costs. Nonprofit and Voluntary Sector Quarterly, 43, 570-588.

20.Chow, C. W., \& Wong-Boren, A. (1987). Voluntary Financial Disclosure by Mexican Corporations. The Accounting Review, 62(3), 533-541.

21.Copps, J., and Vernon, B. (2010). The little blue book, NPC's guide to analysing charities, for charities and funders. London: New Philanthropy Capital.

22.Crowther, D. (2017). Formulation of a sustainable financial management strategy for South African Universities' Hotel Schools (Doctoral dissertation.) Retrieved from:

http://ir.cut.ac.za/bitstream/handle/11462/1893/Crowther\%2C\%20Dalene\%20.pdf?sequence=1\&isAl lowed=y

23.Despard, M.R., Adjabeng, B., Nafziger-Mayegun, R.N. (2016, January). Do Revenue Diversification and Income Generating Activities Promote Financial Sustainability of NGOs in Sub-Saharan Africa? Paper presented at the Society for Social Work and Research 20thAnnual Conference, Washington, DC. Retrieved from: https://www.researchgate.net/publication/296639551_Do_revenue_diversification_and_income_ge nerating_activities_promote_financial_sustainability_of_NGOs_in_Sub-Saharan_Africa

24.DiMaggio, P. J. (1986). Introduction. In P. DiMaggio (Ed.), Nonprofit enterprise and the arts (pp. 3-13). New York: Oxford University Press.

25.DiStefano, C. and Morgan, G.B. (2014). A Comparison of Diagonal Weighted Least Squares Robust Estimation Techniques for Ordinal Data. Structural Equation Modeling: A Multidisciplinary Journal, 21(3),425-438.

26.Doornik, J. and Hansen, H. (2008). An omnibus test for univariate and multivariate normality. Oxford Bulletin of Economics and Statistics, 70, 915-925.

27.Ebrahim, A. (2005). Accountability myopia: losing sight of organisational learning. Non-profit and Voluntary Services Quarterly, 34(1), 56-87.

28.Efron, B. (1987). Better Bootstrap Confidence Intervals. Journal of the American Statistical Association, 82(397), 171-185.

29.Enjolras, B. and Sivesind, K.H. (2018). The Roles and Impacts of the Third Sector in Europe. In B. Enjolras, L.M. Salamon, K.H. Sivesind, A. Zimmer (Eds.), The Third Sector as a Renewable Resource for Europe: Concepts, Impacts, Challenges and Opportunities. Retrieved from https://link.springer.com/chapter/10.1007/978-3-319-71473-8_4

30.Foo, N., and Mohd Rani, N. A. (2017, September 3). Malaysians feeling the economic pinch, giving less to charity now. The Star Online. Retrieved from

http://www.thestar.com.my/metro/community/2017/03/09/drastic-drop-in-donations-welfarehomes-struggle-to-continue-operations-as-contributions-take-a-dive/

31.Foster, M., \& Meinhard, A. (2000). Revenue Diversification as a Strategic Response by Canada's Nonprofit Sector. Toronto: Centre for Voluntary Sector Studies, Ryerson University. Retrieved from http://www.ryerson.ca/content/dam/cvss/files/new-WORKINGPAPERS/WP12\%202000(3)\%20Revenue\%20Diversification....Strategic\%20Response.pdf

32.Froelich, K. A. (1999). Diversification of revenue strategies: Evolving resource dependence in nonprofit organisations. Nonprofit and Voluntary Sector Quarterly, 28, 246-268. Retrieved from https://journals.sagepub.com/doi/pdf/10.1177/0899764099283002 
33.Galaskiewicz, J., and Bielefeld, W. (1998). Nonprofit organizations in an age of uncertainty: A study of organizational change. Piscataway: Transaction Publishers.

34.Gronbjerg, K. A. (1991). Managing grants and contracts: The case of four nonprofit social service organizations. Nonprofit and Voluntary Sector Quarterly, 20(1), 5-24.

35.Gronbjerg, K. A. (1992). Nonprofit human service organizations: Funding strategies and patterns of adaptation. In Y. Hasenfeld (Ed.), Human Services as Complex Organizations (pp. 73-97). Newbury Park, CA: Sage.

36.Grønbjerg, K. A. (1993). Understanding nonprofit funding: Managing revenues in social service and community development organizations. San Francisco: Jossey-Bass.

37.Grove, H., and Basilico, E. (2008). Fraudulent Financial Reporting Detection. Key Ratios Plus Corporate Governance Factors. Int. Studies of Mgt. and Org., 38(3), 10-42.

38. Hair, J. F., Hult, G. T. M., Ringle, C. M., \& Sarstedt, M. (2014). A Primer on Partial Least Squares Structural Equation Modeling. Thousand Oaks: Sage.

39. Henze, N., and Zirkler, B. (1990). A class of invariant consistent tests for multivariate normality. Communications in Statistics, Theory and Methods, 19, 3595-3617.

40.Hooper, D., Coughlan, J. and Mullen, M. R. (2008). Structural Equation Modelling: Guidelines for Determining Model Fit. The Electronic Journal of Business Research Methods, 6 (1), $53-60$. Available at http://www.ejbrm.com/issue/download.html?idArticle=183

41.Hu, L.T. and Bentler, P.M. (1999). Cutoff Criteria for Fit Indexes in Covariance Structure Analysis: Conventional Criteria Versus New Alternatives. Structural Equation Modeling, 6 (1), 1-55.

42.James, L. R. and Brett, J. M. (1984). Mediators, moderators, and tests for mediation. Journal of Applied Psychology, 69(2), 307-321. https://doi.org/10.1037/0021-9010.69.2.307

43.Judd, C. M., \& Kenny, D. A. (1981). Process analysis: Estimating mediation in treatment evaluations. Evaluation Review, 5, 602-619. http:// dx.doi.org/10.1177/0193841X8100500502

44.Keating, E. K., and Frumkin, P. (2003). Reengineering non-profit financial accountability: Toward a more reliable foundation for regulation. Public Administration Review, 63(1), 3-15

45. Keating, E. K., Fischer, M., Gordon, T. P., and Greenlee, J. (2005). Assessing Financial Vulnerability in the Nonprofit Sector (Vol. 1). Cambridge, MA: Harvard University, Hauser Center for Nonprofit Organizations.

46.Kelly, K. S. (1998). Effective fund-raising management. Mahwah, NJ: Lawrence Erlbaum

47.Kim, M. (2014). Does revenue diversification really matter? The power of commercial and donative distinction in the nonprofit arts. University of Pennsylvania Social Impact Fellowship, 1-34. Retrieved from: http://socialimpactstrategy.org/wp-content/uploads/2016/03/Kim.pdf

48.Ko, W.W. and Liu, G. (2020). The Transformation from Traditional Nonprofit Organizations to Social Enterprises: An Institutional Entrepreneurship Perspective. Journal of Business Ethics. Retrieved from https://doi.org/10.1007/s10551-020-04446-z

49.Lewis, T. (2011). Financial sustainability essentials. Course handbook. Oxford: Management Accounting for Non-Governmental Organisations (MANGO).

50.Lin, W. (2010). Nonprofit revenue diversification and organizational performance: an empirical study of New Jersey Human services and community improvement organizations. Rutgers The State University of New Jersey-Newark. Retrieved from http://search.proquest.com/openview/d90fa258ec69319a26e19ddbe5f540d6/1?pqorigsite $=$ gscholar $\& \mathrm{cbl}=18750 \&$ diss $=y$ 
51.MacCallum, R.C., Browne, M.W., and Sugawara, H. M. (1996). Power Analysis and Determination of Sample Size for Covariance Structure Modeling. Psychological Methods, 1 (2), 130-49.

52.MacKinnon, D.P., Fairchild, A.J., and Fritz, M. S. (2007). Mediation Analysis. Annual Review of Psychology, 58(1), 593-614.

53.Mardia, K.V. (1970). Measures of multivariate skewness and kurtosis with applications. Biometrika, $57,519-530$.

54.McQuitty, S. (2004). Statistical power and structural equation models in business research. Journal of Business Research, 57 (2), 175-83.

55.Midot. (2013). Midot guide for effectiveness. Tel Aviv: Midot-analyzing and rating NPOs.

56.Miles, J. and Shevlin, M. (1998). Effects of sample size, model specification and factor loadings on the GFI in confirmatory factor analysis. Personality and Individual Differences, 25, 85-90.

57.Mîndrilă, D. (2010). Maximum Likelihood (ML) and Diagonally Weighted Least Squares (DWLS) Estimation Procedures: A Comparison of Estimation Bias with Ordinal and Multivariate Non-Normal Data. International Journal of Digital Society (IJDS), 1(1), 60-66.

58.Mohamed, M. M., \& Muturi, W. (2017). Factors influencing financial sustainability of local nongovernmental organisations in Puntland, Somalia. International Journal of Social Sciences and Information Technology, 3(2), 1612-1639.

59.Muth, M. M. and Donaldson, L. (1998). Stewardship Theory and Board Structure: a contingency approach. Corporate Governance, 6(1), 5-28.

60.Muthén, B., du Toit, S.H.C. and Spisic, D. (1997). Robust inference using weighted least squares and quadratic estimating equations in latent variable modeling with categorical and continuous outcomes. Unpublished technical report.

61.Nielsen, W. A. (1979). The endangered sector. New York: Columbia University Press.

62.Nik Ahmad, N.N., Ismail, S. and Siraj, S.A. (2019). Financial sustainability of Malaysian public universities: officers' perceptions. International Journal of Educational Management, 33(2), 317-334.

63. Njoroge, G. B. (2013). An investigation on the factors influencing sustainability of NGO'S in Kenya. University of Nairobi, Kenya. Retrieved from:

http://chss.uonbi.ac.ke/sites/default/files/chss/BONIFACE\%20NJOROGE\%20GATHEE\%20D63-758102012.pdf

64.Nyanumba, P., Rotich, G., Gekara, M., Keraro, V., \& Okari, H. (2017). Influence of Revenue Diversification on Performance of Counties in Kenya. International Journal of Innovative Finance and Economics Research, 5(2), 11-20.

65.Ochieng, A. G. A. (2016). The Effects Of Funding Diversification On Financial Sustainability Of NonGovernmental Organizations In Nairobi County. University of Nairobi, Kenya.

66.Ohlson, J. A. (1980). Financial ratios and the probabilistic prediction of bankruptcy. Journal of Accounting Research, 18(1), 109-131.

67.Okorley, E., Deh, J. and Owusu, R. (2012). A Ghanaian case study of strategies of ensuring accountability by non-governmental organisations. Journal of Sustainable Development in Africa, 14(7), 43-54.

68.Omar, N., Arshad, R., \& Razali, W. A. A. W. M. (2013). Assessment of Risk Using Financial Ratios in NonProfit Organisations. Journal of Energy Technologies and Policy, 3(11), 382-389.

69. Organisation for Economic Co-operation and Development (OECD). (1995). Development Cooperation: Efforts and Policies of the Members of the Development Assistance Committee. Chairman's Report, 1994. Paris: OECD. 
70.Pardo, A., and Roman, M. (2013). Reflections on the Baron and Kenny model of statistical mediation. Anales de psicologia, 29(2), 614-623.

71.Parker, L.D. (2003). Financial Management Strategy in a Community Welfare Organisation: A Boardroom Perspective. Financial Accountability \& Management, 19(4), 341-374.

72.Peterson, P. A. (1986). From impresario to arts administrator. In P. DiMaggio (Ed.), Nonprofit enterprise and the arts (pp. 161-183). New York: Oxford University Press.

73.Pfeffer, J., and Salancik, G. R. (1978). The external control of organizations. New York: Harper and Row.

74.Pfeffer, J. and Salancik, G. R. (2003). The external control of organizations: A resource dependence perspective. Stanford, CA: Stanford University Press.

75.Powell, W. W., \& Owen-Smith, J. (1998). Universities and the market for intellectual property in the life sciences. Journal of Policy Analysis and Management, 17, 253-277.

76.Powell, W.W. and Friedkin, R. (1987). Organizational Change in Nonprofit Organizations. In W.W. Powell (Ed.), The Nonprofit Sector: A Research Handbook. New Haven CT: Yale University Press, 1987.

77.Preacher, K. J., and Hayes, A. F. (2004). SPSS and SAS procedures for estimating indirect effects in simple mediation models. Behavior Research Methods, Instruments, and Computers, 36, 717-731.

78.Reed, P.B. and Howe, V.J. (1999). Defining and Classifying the Nonprofit Sector. Available at http://citeseerx.ist.psu.edu/viewdoc/download?doi=10.1.1.502.193\&rep=rep1\&type=pdf

79.Rosseel, Y. (2012). lavaan: An R Package for Structural Equation Modeling. Journal of Statistical Software, 48(2), 1-36. Retrieved from: http://www.jstatsoft.org/v48/i02/

80.Ryan, C., and Irvine, H. J. (2012). Not-for-profit ratios for financial resilience and internal accountability: A study of Australian international aid organisations. Australian Accounting Review, 22(2), 177-194.

81.Salamon, L. M., and Anheier, H. K. (1997). The Third World's Third Sector in Comparative Perspective. Baltimore: The Johns Hopkins Institute for Policy Studies. Retrieved from http://www.admcf.com/jhu/pdfs/CNP_Working_Papers/CNP_WP24.pdf

82.Saungweme, M. (2014). Factors influencing financial sustainability of local NGOs: the case of Zimbabwe. Stellenbosch University, South Africa. Retrieved from: https://oatd.org/oatd/record?record=handle\%5C\%3A10019.1\%5C\%2F97293

83.Scurto-Davis, T. (2014). Earned Revenue Ratio: Its Effect on Non-profit Financial Sustainability. Drexel University, Philadelphia, US.

84.Shannon, J. (1987). State Revenue Diversification - The Search for Balance, Tax Policy Roundtable, Property Tax Papers Series TPR-16. In F.D. Stocker (Ed.), The Quest for Balance in State-Local Revenue Structures (pp.9-37). Cambridge, MA: Lincoln Institute of Land Policy.

85.Simsa, R., Rausher, O., Schober, C., \& Moder, C. (2014). Methodological guidelines for impact assessment. Third Sector Impact Working Paper No. 1, The Roles and Impacts of the Third Sector in Europe Seventh Framework Programme (grant agreement 613034). European Union. Brussels: Third Sector Impact.

86.Singh, S., \& Mofokeng, M.-A. (2014). An analysis of what makes a non profit organisation sustainable: specific reference to revenue diversification. Interdisciplinary Journal of Contemporary Research in Business, 6(2), 393-424.

87.Tevel, E., Katz, H., \& Brock, D. M. (2014). Nonprofit Financial Vulnerability: Testing Competing Models, Recommended Improvements, and Implications. VOLUNTAS: International Journal of Voluntary and Nonprofit Organizations. https://doi.org/10.1007/s11266-014-9523-5

88.Tuckman, H. P., and Chang, C. F. (1991). A methodology for measuring the financial vulnerability of charitable nonprofit organisations. Nonprofit and Voluntary Sector Quarterly, 20, 445-460. 
89.Useem, M. (1987). Corporate philanthropy. In W. Powell (Ed.), The nonprofit sector: A research handbook (pp. 340-359). New Haven, CT: Yale University Press.

90.von Schnurbein, G. and Fritz, T.M. (2017). Benefits and Drivers of Nonprofit Revenue Concentration. Nonprofit and Voluntary Sector Quarterly, 46(5), 922-943.

91.Waiganjo, E.W., Ng'ethe, J.M. and Mugambi, D.N. (2012). An investigation into the strategies adopted by non-governmental organisation in Kenya to increase financial sustainability. International Journal of Current Research, 4(4), 74-78.

92.Webb, J. (2015). A path to sustainability: How revenue diversification helps colleges and universities survive tough economic conditions. Journal of International \& Interdisciplinary Business Research, 2, 69-97. Available at: http://scholars.fhsu.edu/jiibr/vol2/iss1/7

93. White, F.C. (1983). Trade-Off in Growth and Stability in State Taxes. National Tax Journal XXXVI(1), 103114.

94.Wicker, P., Feiler, S., \& Breuer, C. (2013). Organizational Mission and Revenue Diversification among Non-profit Sports Clubs. International Journal of Financial Studies, 1(4), 119-136. https://doi.org/10.3390/ijfs1040119

95.Wong, D. (2016, April 10). Bigger charities feel the pinch, too. Retrieved April 15, 2017, from http://www.nst.com.my/node/138309

96.Yan, W., Denison, D. V., \& Butler, J. S. (2009). Revenue structure and nonprofit borrowing. Public Finance Review, 37(1), 47-67.

97.Yasmin, S., Haniffa, R., \& Hudaib, M. (2014). Communicated Accountability by Faith-Based Charity Organisations. Journal of Business Ethics, 122(1), 103-123. https://doi.org/10.1007/s10551-013-17592

98.Young, D. R., and Salamon, L. M. (2002). Commercialization, social ventures, and for-profit competition. In L. M. Salamon (Ed.), The State of Nonprofit America (pp. 423-446). Washington, DC: Brookings Institution Press.

99.Zaharrudin, N. Z., Zakaria, A., \& Zakaria, A. (2018). The Contributing Sources for Sustainable Funding in Malaysian Social Welfare Group. International Journal of Academic Research in Business and Social Sciences, 8(11), 2111-2121.

100. Zhu, J., Ye, S. \& Liu, Y. (2018). Legitimacy, Board Involvement, and Resource Competitiveness: Drivers of NGO Revenue Diversification. VOLUNTAS: International Journal of Voluntary and Nonprofit Organizations, 29(6), 1176-1189.

101. Zimmerman, M. A., \& Zeitz, G. J. (2002). Beyond survival: Achieving new venture growth by building legitimacy. Academy of Management Review, 27(3), 414-431. 